\title{
Promoting Critical Thinking in Multilingual Mathematics Classes through Questioning
}

\author{
Clemence Chikiwa ${ }^{1^{*}}$, Marc Schäfer ${ }^{2}$ \\ ${ }^{1}$ Rhodes University, Professional Development Centre, Grahamstown, SOUTH AFRICA \\ ${ }^{2}$ Rhodes University Education Department, Grahamstown, SOUTH AFRICA
}

Received 30 January 2018 - Revised 16 April 2018 • Accepted 1 May 2018

\begin{abstract}
This study explores how teacher questioning was used to foster critical thinking in selected Grade 11 multilingual mathematics classes in the Eastern Cape Province. A mixed-method design was used to collect and analyse both qualitative and quantitative data through classroom observations and interviews of three purposively selected Grade 11 mathematics teachers during their teaching of trigonometry and analytical geometry. The study was guided by Bloom's revised taxonomy. The study found that teachers in these multilingual classes used lower-order levels of questioning during teaching. Higher-order questions, which research has shown have the potential of promoting critical thinking, were infrequently used during teaching. The paper concludes that, while all the categories of Bloom's taxonomy are important, the ones that are crucial in promoting critical and higher-order thinking required at Grade 11 were not adequately used. Suggestions for improving questioning in mathematics teaching are explored.
\end{abstract}

Keywords: code-switching, critical thinking, multilingual, questioning

\section{INTRODUCTION}

Oral questioning is crucial in the teaching and learning environment. Teacher questioning may be used as a teaching strategy in its own right, or as part of any other strategy, during instruction. Teacher questioning plays a critical role in mathematics classes for cultivating critical-thinking skills and thereby fostering deeper learning. The teaching of mathematics in South Africa's township and rural secondary school classrooms is usually conducted using the combination of languages spoken in a given community. This mix of the language of learning and teaching (LOLT) and indigenous languages occurs through code-switching which is an alternate use of two or more languages in a conversation or an utterance (Adler, 2001; Baker, 1993). Code-switching practices that incorporates indigenous languages are a feature of many South African classrooms where teachers and learners share a common home language, while the LOLT is English (Probyn, 2009). The use of an indigenous language by the teacher provides a communicative resource to facilitate learning when students lack proficiency in the LOLT (Then \& Ting, 2011). Code-switching in this paper will refer to all the ways in which teachers orally use South Africa's indigenous languages during the teaching of mathematics.

The majority of learners in rural and township schools are taught mathematics in a language that is neither their first, nor one that is commonly spoken in the communities in which these learners live. This presents additional challenges associated with language uses during teaching. The LOLT is, in most cases, not developed to a level which these learners can comfortably use as a medium of instruction (Chikiwa \& Schäfer, 2016). This presents teachers with a dual task of teaching mathematics in the LOLT and translating some concepts to the learners' first language in ensuring these learners grasp the mathematical concepts.

Teachers thus often ask questions in two or more languages through code-switching. In cases where the LOLT is not the learners' home language, many research studies in the field of mathematics education refute the assumption that the learners' home language is not necessary and should be ignored in multilingual classes (Setati, 2008). Some studies, for example Cummins (2000), proposed that learners who can converse in two or more

(C) 2018 by the authors; licensee Modestum Ltd., UK. This article is an open access article distributed under the terms and conditions of the Creative Commons Attribution License (http://creativecommons.org/licenses/by/4.0/). \.chikiwa@ru.ac.za cchikiwa@gmail.com (Correspondence) $\square$ m.schafer@ru.ac.za 


\section{Contribution of this paper to the literature}

- There are not many papers published in respected journals linking language use by teachers to critical thinking in multilingual classes.

- The benefits of code-switching as a potential teaching resource are discussed and suggestions made on how it can be used optimally in mathematics multilingual classes.

- This paper provides suggestions for improving questioning to promote critical thinking during mathematics instruction when teachers are teaching in neither their first nor the learners' first language.

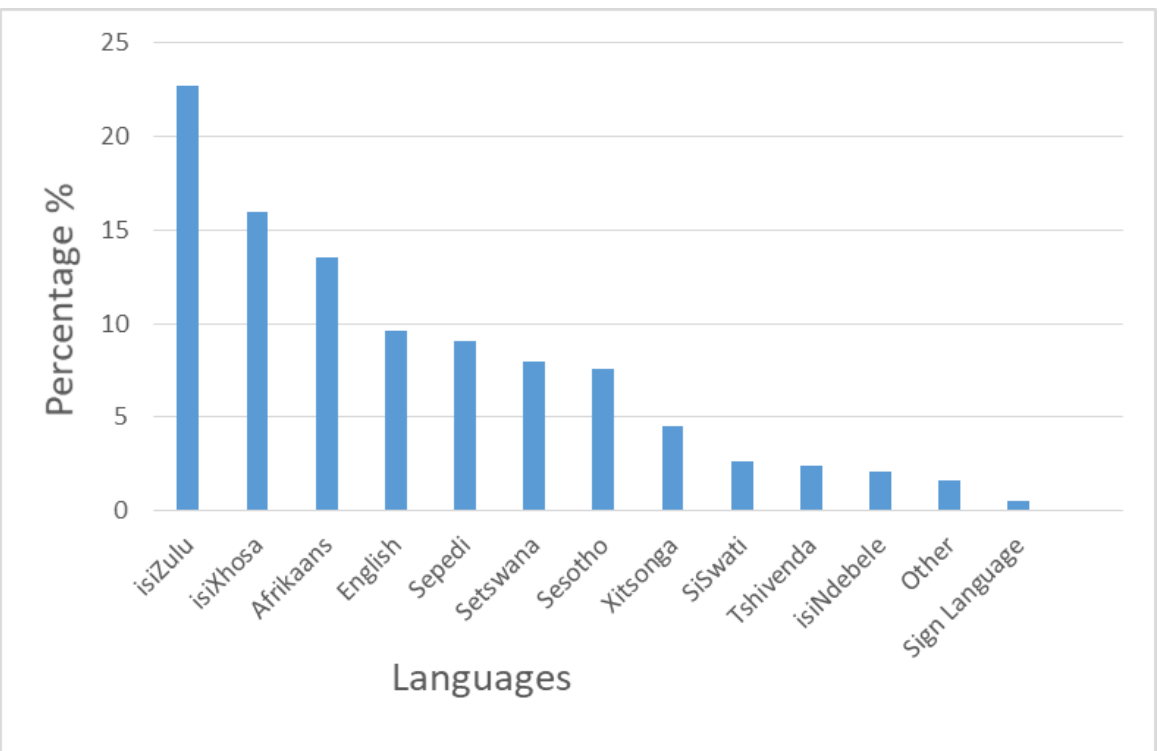

Figure 1. Distribution of the South African population by the first language spoken (percentage) [Source: Statistics South Africa Census 2011]

languages and are permitted to use them during learning will perform better than their peers who do not. "The goal of education is for learners to ultimately think critically, learn, analyze, criticize and develop skills to solve familiar and unfamiliar problems. This implies that questions that encourage critical thinking should be part of the instructional repertoire of all teachers of mathematics" (Sillivan \& Lilburn, 2002, p. 1). Thus, teachers' language practices that provoke student thinking leading to deeper conceptual understanding of concepts are vital for promoting meaningful engagement and learning in mathematics classrooms.

The need to use learners' home language to ask questions that promote deeper conceptual learning, long-lasting understanding and critical thinking, needs to be looked at more closely. Over the past three decades, research has increased on language-related factors and how they directly influence successful conceptual teaching and learning of mathematics in South Africa's multilingual classes (Chikiwa \& Schäfer, 2016; Setati, 2008). In an era where various societal and educational sectors are advocating visible transformation and quality decolonised education, language-related factors in teaching and learning at school level are paramount. Components that entail day-today functions of a mathematics class need to be investigated in promoting effective teaching and meaningful learning in mathematics in today's secondary school mathematics classroom. Thus, in the light of teachers using pupils' first language in South African's mathematics classrooms, this paper focuses on how teacher questions posed in pupils' home language through code-switching fostered critical thinking during teaching. We thus sought to address the following questions: What teacher questions are prevalent in multilingual mathematics classroom? What forms of thinking do multilingual mathematics teacher questions promote? How can mathematics teachers use questions to promote critical-thinking during their teaching of multilingual classes?

\section{BACKGROUND AND CONCEPTUAL FRAMING}

\section{Language Landscape and Policy in the Eastern Cape Province}

The advent of democracy in 1994 in South Africa led to the institution of 11 official languages (Figure 1), up from two (English and Afrikaans) that had official status during the apartheid era. While this was a positive initiative to ensure African languages are recognized and used for official purposes, it brought challenges. 
Although all the 11 languages are official and equal under the constitution, their status in education is not equal. IsiXhosa, for instance, is spoken by around $80 \%$ of South Africans in the Eastern Cape Province (SA Statistics, 2012); this implies that isiXhosa is spoken as a first language by more than three-quarters of the population in this province, while English is spoken as a first language by only $5.6 \%$ of the total population in the province (SA Statistics, 2012). Therefore, the majority of rural and township schools in the Eastern Cape Province use the first language of the minority, which is English, as the LOLT at secondary school level. This can be seen in Figure 1 which shows that only about 9\% of South Africa's population speak English as their first language. We thus argue that the use of an unfamiliar language, English, continues to perpetuate inequalities through education. OwenSmith (2010, p. 31) argued that "any child who cannot use the language which he/she is most familiar with (usually the home language), is disadvantaged and unlikely to perform to the best of his/her ability". The perpetuation of this unfortunate situation in South Africa is because of complex interactions of historical, political, economic and social factors over centuries of apartheid legacy.

The South African Language-in-Education Policy (LiEP) of 1997 mandates that schools can decide on their own language policies in consultation with parents. The LiEP of 1997, in essence, affords all students the right to be taught in the language of their choice. This legislative framework was enacted with an understanding that all indigenous African languages are capable of functioning as a LOLT. In most schools from Grade 4 in South Africa, the LOLT chosen by them is English despite the fact that the majority of learners have little exposure to English outside the classroom. This situation pertains in the Eastern Cape (Probyn, 2009); KwaZulu-Natal (Zuma \& Dempster, 2008); Limpopo (Setati, 2005); and North-West (Carnoy et al., 2011). This implies that the official language policy of any region and the schools' position on the use of home languages through code-switching go a long way towards setting a context for the acceptance, rejection, systematic use or lack of use of African languages in educational settings (Mafela, 2009).

In the Eastern Cape, the empirical site of this study, most schools, including those identified for this study, have English as their LOLT despite the fact that the vast majority of the teachers and learners in these schools are isiXhosa first-language speakers. Alidou and Brock-Utne (2011, p. 160) identified that "studies related to language of instruction issues in post-colonial Africa unanimously suggest that the maintenance of languages such as English, French and Portuguese as dominant or exclusive languages of instruction creates teaching and learning problems in African schools". This is mainly because the majority of learners, and to some extent teachers in these communities, are not fluent in the LOLT resulting in communication, teaching and learning problems in mathematics classrooms.

The use of home languages as a medium for mathematics teaching and learning in South African schools is a much-debated topic. It has been observed that in general both parents and learners prefer English to be the LOLT (Probyn, 2009). This is driven by various factors from within and outside school settings. Probyn (2009) further suggested that English is likely to remain the chosen LOLT at school level and in teacher education institutions for the next foreseeable future. Setati (2008) argued that this is so because decisions on language policy in South Africa have to accommodate many competing historical, political, economic, social and educational factors. The result has been that the mathematics teachers' responses to the LOLT chosen by the school has been to use a combination of both the pupils' home language and the chosen LOLT through the medium of code-switching.

\section{Code-switching and Teacher Training in South Africa}

Code-switching occurs when a teacher substitutes a word or phrase in one language with a phrase or word in a second language (Baker, 1993). It is defined as the use of more than one language in the same conversation or utterance (Adler, 2001; Choudhury \& Bose, 2011). In South Africa, code-switching is now widely accepted and viewed as a legitimate resource for supporting school mathematics' teaching and learning in multilingual classes (Adler, 2001; Setati, 2008). It is considered as a practice in which teachers and their pupils who are learning mathematics in a second language can harness their main language as a learning resource (Setati, Adler, Reed, \& Bapoo, 2002).

Wildsmith-Cromarty (2012), while acknowledging that teacher language practices such as code-switching in science and mathematics classrooms appears to be an already established practice, concluded that:

The challenge is, therefore, to understand how to harness this code-switching practice in a systematic way in order to enhance conceptual development in the mother or primary language. We need further research in order to ascertain whether the type of code-switching used by teachers truly builds an academic understanding of a concept, or whether it dilutes scientific meanings through the use of colloquial examples (p. 166).

Research is needed to analyse code-switching practices of mathematics teachers and interrogate how such practices build and support critical thinking in learners. This is because the choice of unfamiliar languages such as English, as the LOLT in rural and township schools, has been observed to significantly encourage mathematics teaching practices and strategies such as rote learning (Setati \& Adler, 2001); safe talk (Chick, 1996); and recall, 
memorisation and chorus teaching (Alidou \& Brock-Utne, 2011). In such classrooms, mathematics teachers do most of the talking, relying prevalently on traditional teaching strategies.

Legitimization and use of code switching in mathematics teaching has been done with little or no attention to whether teachers were trained to teach in any other language except English or Afrikaans in South Africa. Probyn (2015, p. 220) concluded that "in South Africa, although there has been an unofficial drift towards recognizing codeswitching as a valid classroom strategy, there is little training that guides teachers towards a coherent systematic approach to using both languages in the classroom in ways designed to enhance opportunities to learn". In other words, while the use of indigenous languages through code-switching is now a common phenomenon in South Africa's mathematics classrooms (Rose \& van Dulm, 2006), teachers are left to make their own day-to-day decisions as to when, where and how to code switch during teaching.

Wildsmith-Cromarty (2012) noted that most teachers did not acquire their mathematical knowledge through an African language since such languages were (and still are) not available as the LOLT during their period of training. This then makes it difficult for most teachers to transfer mathematical knowledge from English to an indigenous African language. Pimm (1987) emphasised that knowing the mathematics register in one language (for example, second language) does not automatically mean that the same individual knows this mathematics in another language (say her/his first language). Essien (2013) also supported the idea that teachers would need to be trained to teach in indigenous African languages. Teachers should not be expected to automatically and correctly teach or transmit into an African language what they learn in English. This problem is compounded by the fact that, in the context of this study, there does not exist an agreed mathematics register in isiXhosa.

Prediger, Clarkson and Bose (2012) concluded that because empirical analysis has shown that code-switching can enhance teaching and learning, it is important "... to develop and promote teaching strategies that make more purposeful use of code-switching and other links between first and second languages" (p. 6214). This implies that the use of indigenous languages through code-switching cannot be left to chance or to occur unchecked. There needs to be deliberate steps towards promotion of the systematic and purposeful use of indigenous languages through code-switching during teaching. While this study embraces the notion of code-switching as a legitimate strategy employed by teachers during teaching, we specifically wish to analyse how code-switching, as a linguistic medium, promotes critical thinking through questioning.

\section{Critical Thinking through Teacher Questioning}

Critical thinking is a way of making reasoned decisions or judgements about whether a claim, statement or any phenomenon posed is false, true or partially true. In the teaching of content subjects like mathematics, critical thinking enhances creative problem-solving options as it encourages learners to seek new strategies (Paul \& Elder, 2008). Elder and Paul (1994: p. 34) stated that "critical thinking is best understood as the ability of thinkers to take charge of their own thinking". Such a skill helps learners to think of adequate support to any claim, or belief they might have about mathematics. Students who are taught to think critically take charge of their own thinking and are able to monitor it. According to Paul (1990), critical thinking is "thinking about your thinking while you're thinking, in order to make your thinking better" (p. 91). Presented with various mathematical situations, a criticalthinking learner will always monitor her/his own thinking, making sure that no premature conclusion or solution is provided.

As argued by Duron, Limbach and Waugh (2006), critical thinkers raise vital questions and problems, they formulate these questions clearly to gather and access relevant information they would use to base their judgements. Bloom's work, as revised by Anderson and Krathwohl (2001), identified six levels within the cognitive domain that forms the primary base on which some critical-thinking theory rests. The last three levels, analysis, evaluating and creating focus specifically on what learners require to think critically.

One way to promote critical thinking is to ask appropriate questions framed at the right cognitive level in the teaching and learning of mathematics. Critical thinking is characterized by a readiness to question all assumptions, an ability to recognize when it is necessary to question, and an ability to evaluate and analyse (Duron, Limbach, \& Waugh, 2006). Critical thinking has been widely recognized and encouraged in education for many years, and using questioning techniques is one way that teachers can inspire critical thinking.

Questioning is indispensable and all-important in the teaching and learning of mathematics. Thinking is largely driven by questions and not solutions. Questions are mostly essential for driving thinking during teaching and learning. Paul (2007, no page) argued that "if you have very few questions, you have very little to think about". While there are many strategies mathematics teachers may use to influence learners' thinking, Clasen and Bonk (1990) posited that teacher questions have the greatest impact. For learners to think through their work or rethink their solutions to given mathematics tasks, they must be asked questions that stimulate thought. The level of learners' thinking was found by Clasen and Bonk (1990) to be directly proportional to the nature and level of questions teachers ask. 
Table 1. Revised Bloom's Taxonomy Adapted from Anderson and Krathwohl (2001)

\begin{tabular}{|c|c|c|}
\hline Category & Generic skills & Sample Verbs \\
\hline Remembering & $\begin{array}{l}\text { Questions posed require learners to recall and } \\
\text { remember learned information. }\end{array}$ & $\begin{array}{l}\text { Choose, Cite, Define, Enumerate, Group, Label, List, } \\
\text { Match, Name, Outline, Repeat, Select, Sort, State, } \\
\text { Underline }\end{array}$ \\
\hline Understanding & $\begin{array}{l}\text { Question posed seeks for evidence of grasp of } \\
\text { meaning of information by interpreting or translating } \\
\text { what has been learned. }\end{array}$ & $\begin{array}{l}\text { Account for, Classify, Convert, Define, Describe, } \\
\text { Discuss, Estimate, Explain, Identify, Indicate, Interpret, } \\
\text { Report }\end{array}$ \\
\hline Applying & $\begin{array}{l}\text { Teacher questions require learners to make use of } \\
\text { information in a new situation from the one in which it } \\
\text { was learned. }\end{array}$ & $\begin{array}{l}\text { Apply, Calculate, Change, Compute, Construct, Draw, } \\
\text { Illustrate, Interpret, Make, Show, Sketch, Solve }\end{array}$ \\
\hline Analysing & $\begin{array}{l}\text { Teacher questions require learners to break learned } \\
\text { information into its parts to best understand that } \\
\text { information in an attempt to identify evidence for a } \\
\text { conclusion. }\end{array}$ & $\begin{array}{l}\text { Analyse, Arrange, Calculate, Categorise, Compare, } \\
\text { Contrast, Diagram, Distinguish, Investigate, Order, } \\
\text { Relate, Sequence, Subdivide }\end{array}$ \\
\hline Evaluating & $\begin{array}{l}\text { Questions that require learners to make decisions } \\
\text { based on in-depth reflection, criticism and assessment. }\end{array}$ & $\begin{array}{l}\text { Assess, Choose, Compare, Conclude, Deduce, } \\
\text { Determine, Differentiate, Evaluate, Infer, Measure, } \\
\text { Score, Select }\end{array}$ \\
\hline Creating & $\begin{array}{l}\text { Questions that require learners to create new ideas and } \\
\text { information using what has been previously learned. }\end{array}$ & $\begin{array}{l}\text { Combine, Construct, Create, Design, Develop, } \\
\text { Formulate, Forecast, Hypothesize, Organise, Predict }\end{array}$ \\
\hline
\end{tabular}

Questions that demand critical thinking drive thought processes to look beneath the surface of things. In the context of the mathematics classroom, critical thinking encourages teachers and learners to delve beyond the surfaced definition of a mathematical concept. It encourages teachers and learners to interrogate the multitude of complexities of a mathematical concept or idea. Paul and Elder (2008) observed that, unfortunately, some teachers are themselves not generators of critical questions and answers of their own. This can result in superficial engagement, thinking and reflecting on their own teaching of mathematics. Paul and Elder (2008) asserted that many teachers are purveyors of questions and answers of others, usually those of a textbook and other materials developed by others, not themselves. This makes mathematics teaching and learning an impoverished exercise that may not result in intended objectives such as producing learners who are capable of thinking critically. This study focuses on how teacher questioning in the home language through code-switching was used to cultivate critical thinking in Grade 11 mathematics multilingual learners.

\section{Bloom's Taxonomy}

In this study, we used the revised Bloom's taxonomy to analyse teacher language in questions. Bloom and others originally developed this classification in 1956, which has since been revised by a number of other authors. Below is Bloom's taxonomy as revised by Anderson and Krathwohl (2001) with modified terms and emphases. This adapted Bloom's model has changed knowledge to remembering and the highest level of development is creating (synthesis) rather than evaluation. Verbs (indicating activity) are used in preference to nouns. This change was necessitated by the need to better reflect the nature of thinking defined in each of the categories.

A strength of Bloom's Taxonomy, in our view, is its ability to distinguish between higher- and lower-order thinking skills. This has assisted in raising awareness of the need to foster critical thinking during teaching and learning. It must be emphasized that Bloom's categories are not in themselves independent from each other, but are decidedly interdependent (Paul \& Elder, 2008). A close analysis of the South African mathematics curriculum's specification of content to be taught (Department of Basic education (DBE), 2011) shows that Bloom's revised taxonomy has informed the framing, designing and organisation of objectives and assessment tasks. This is because the taxonomy reflects different forms of thinking and thinking as an active engagement hence the use of action verbs to represent intended cognitive processes instead of nouns.

Dori and Herscovitz (1999) argued that the questions teachers ask reflect the level of thought required from the learner to answer them. They can therefore be ranked. Both Bloom's earlier and revised taxonomy of cognitive objectives is useful in formulating and planning questions that require low to high-level thinking. The levels include: remembering/ knowledge, understanding/ comprehending, applying, analyzing, evaluating and creating (Table 1). Teacher questions that elicit responses in the knowledge, understanding, and application domains are frequently considered lower-order questions, while questions that require learners to analyse, evaluate, and create are considered higher-order questions. Teachers who create learning environments in which learners interact in the upper three levels are exposing their learners to critical thinking (Limbach \& Waugh, 2010). While lower-order questions are equally important, higher-order questions elicit deeper and critical thinking, thus, teachers are encouraged to ask questions in these domains as well. 
Table 2. Summary of Participants and Data Collected

\begin{tabular}{cccccccc}
\hline Participant & Gender & Qualifications & $\begin{array}{c}\text { Mathematics } \\
\text { teaching } \\
\text { experience }\end{array}$ & $\begin{array}{c}\text { Levels } \\
\text { taught }\end{array}$ & $\begin{array}{c}\text { Teacher's } \\
\text { first } \\
\text { language }\end{array}$ & $\begin{array}{c}\text { Number of 1- } \\
\text { hour lessons } \\
\text { observed }\end{array}$ & $\begin{array}{c}\text { Number of } \\
\text { end-of-lesson } \\
\text { interviews }\end{array}$ \\
\hline A & Female & $\begin{array}{c}\text { B Ed Honours } \\
\text { Maths }\end{array}$ & 20 Years & $\begin{array}{c}\text { FET and } \\
\text { Senior Phase }\end{array}$ & isiXhosa & 5 & 5 \\
\hline B & Male & B Ed Maths & 18 Years & FET & isiXhosa & 5 & 5 \\
\hline C & Male & B Ed Maths & 18 Years & $\begin{array}{c}\text { FET and } \\
\text { Senior Phase }\end{array}$ & isiXhosa & 5 & 5 \\
\hline
\end{tabular}

Using Bloom's taxonomy, the analysis level requires teachers to formulate questions that demonstrate an ability to determine internal relationships, ability to visualize patterns, to question, classify information, concepts and theories into component parts. Teacher questions at the synthesis level require students to demonstrate abilities to relate knowledge from several areas within and outside a given curriculum to create new or original concepts or ideas. Bloom's revised version provides a valuable framework for mathematics teachers and curriculum designers to use to focus on higher order thinking (Anderson, 2002).

In this study, we are not claiming that once teachers incorporate questions that call for analysis, synthesis and evaluation, then, they are teaching learners to think critically. Rather, we are suggesting that teachers who at least use such questions during teaching are to a significant extent promoting critical thinking more than those who do not. It is widely acknowledged that lower-order questions limit learners' critical thinking and deep understanding of any subject matter including mathematics (Qashoa, 2013; Schneider, 2001).

\section{SAMPLE AND RESEARCH PROCESS}

This study used a case-study approach that enabled the researchers to gain detailed knowledge of teacher language used during questioning when they were teaching geometry in multilingual classrooms. Three Grade 11 mathematics teachers from three districts in the Eastern Cape Province of South Africa were purposively selected to participate in this study. As explained by Denzin and Lincoln (2000), purposive sampling groups participants according to pre-selected criteria relevant to a particular research question. The following criteria were used to select the sample of teachers for this study:

- Mathematics teachers who were fluent in isiXhosa, the language of the majority of learners in their classes.

- Mathematics teachers who were teaching at Further Education and Training phase (FET) of the South African curriculum and were willing to participate in this study.

- Teachers with at least five years' experience of teaching mathematics at secondary level and therefore are well experienced. This is to minimize the possibility that their language practices might be due to lack of teaching experience or recognized qualification. Each of the three teachers had more than 10 years' mathematics teaching experience.

- Teachers who teach at schools where code-switching is prevalent.

Participants' identity remained anonymous; hence the three teachers were identified as Teacher A, Teacher B and Teacher C. All appropriate ethical considerations were followed in this study The LOLT of all the three classes was English and the home language of the majority of learners was isiXhosa. Each teacher and her/his class constituted a case. A summary of participants is given in Table 2.

Each teacher was observed for five consecutive one-hour lessons in a week teaching trigonometry and analytical geometry. Lesson observations were used to identify teacher language used to formulate questions during teaching. Lessons were video-recorded, focusing only on the teacher and the language used. At the end of each lesson, each teacher was interviewed, following up on the language teachers had used during the lesson. Thus, multiple sources of data were used (Table 3). The use of mixed methods in the collection and analysis of data enhanced the validity of results. 
Table 3. Data-collection Matrix

\begin{tabular}{|c|c|c|c|c|}
\hline \multirow{2}{*}{ Descriptors } & \multirow{2}{*}{ Explanation of descriptor } & \multicolumn{3}{|c|}{ Data sources } \\
\hline & & Observations & Documents collected & Interviews \\
\hline $\begin{array}{l}\text { Materials used during } \\
\text { teaching }\end{array}$ & $\begin{array}{l}\text { Teaching materials used by teachers to } \\
\text { plan for teaching and to conduct teaching }\end{array}$ & $x$ & $x$ & $x$ \\
\hline $\begin{array}{l}\text { Teacher Questioning } \\
\text { (TQ) }\end{array}$ & $\begin{array}{l}\text { Forms of language used by the teacher to } \\
\text { structure questions during teaching. }\end{array}$ & $x$ & $x$ & \\
\hline $\begin{array}{l}\text { Teacher Explanations } \\
\text { (TE) }\end{array}$ & $\begin{array}{l}\text { Words used by participants to explain } \\
\text { mathematical concepts. }\end{array}$ & $x$ & & $x$ \\
\hline $\begin{array}{l}\text { Classroom Management } \\
(\mathrm{CM})\end{array}$ & $\begin{array}{l}\text { Language used by participants to manage } \\
\text { their classes during teaching. }\end{array}$ & $\mathrm{x}$ & & $x$ \\
\hline $\begin{array}{l}\text { Classroom Assessment } \\
\text { (CA) }\end{array}$ & $\begin{array}{l}\text { Language used by participants to assess } \\
\text { their classes during teaching. }\end{array}$ & $\mathrm{x}$ & & $x$ \\
\hline $\begin{array}{l}\text { Responding to Student } \\
\text { Contribution }(\mathrm{RC})\end{array}$ & $\begin{array}{l}\text { Forms of language used by the teacher to } \\
\text { respond to learners' contributions during } \\
\text { teaching. }\end{array}$ & $\mathrm{x}$ & & $\mathrm{x}$ \\
\hline Evaluative Remarks (ER) & $\begin{array}{l}\text { Language used by the teacher to praise } \\
\text { and compliment learners. }\end{array}$ & $\mathrm{x}$ & & $x$ \\
\hline
\end{tabular}

The videos were transcribed and analysed in two stages. First, quantitative analysis was done to identify the frequency of the home language used across various lesson categories (Table 3). These lesson categories were developed from Gumperz's (1982) and Mercer's (1995) work. These lesson categories were responding to student contribution (RC), teacher questioning (TQ), teacher explanations (TE), classroom assessment (CA), evaluative remarks (ER) and classroom management $(\mathrm{CM})$. This was followed by the qualitative analysis using the revised Bloom's taxonomy (Anderson \& Krathwohl, 2001). Key isiXhosa words and phrases used by teachers to formulate their questions were considered and categorised guided by generic skills and sample verbs provided for in Table 1. Our categorisation of teacher questions using this taxonomy was not exclusive and as such decisions as to where to categorise a question was only arrived at taking the context in which the question was posed into account.

Trends and patterns emerged during the quantitative analysis relating to all lesson categories across participating teachers. In the second stage of analysis, teacher questioning (TQ) trends and patterns that emerged in the first stage were followed up during the qualitative data-analysis process. The qualitative analysis used two teacher code-switching practices that emerged during the quantitative analysis process. These were referred to as borrowing code-switching (BCS) and transparent code-switching (TCS).

Borrowing code-switching strategies (BCS) referred to where a teacher would borrow from the English language either by retaining the English spelling or by adapting the phonology of the borrowing language (Baker, 2011). Transparent code-switching strategies (TCS) referred to all code-switching where meaning of terms was not concealed but noticeable, self-evident and transparent to students (Meaney, Trinick, \& Fairhill, 2012).

\section{DATA ANALYSIS AND DISCUSSION}

In the lessons observed, the three teachers were teaching trigonometry and analytical geometry. They were dealing with different concepts of these topics in the week they were observed. This paper focuses only on how teacher questioning was used to foster critical thinking during instruction of these lessons.

Of the six lesson categories considered in this study, the participating teachers used the home language more frequently during questioning (TQ) and explaining (TE) (Figure 2). The high frequency of questioning was important as supported by Paul (2007, no page) who argued: "At every point in class, at every moment of instruction, there is a question on the floor. Because if there is no question on the floor there is nothing to think about". At least $22 \%$ of the questions asked by the teachers in this study were presented in the home language. The learners' first-language frequency used during questioning by these teachers is presented in Figure 2 (A 33\%; B $41 \%$; C $22 \%$ ). This implies that if such frequent use of home language is utilized in a manner that may not promote critical thinking, many opportunities are being missed by these teachers to encourage and develop this essential skill in learners. The following sections focus on the qualitative analysis of some of the questions teachers presented to their classes. 


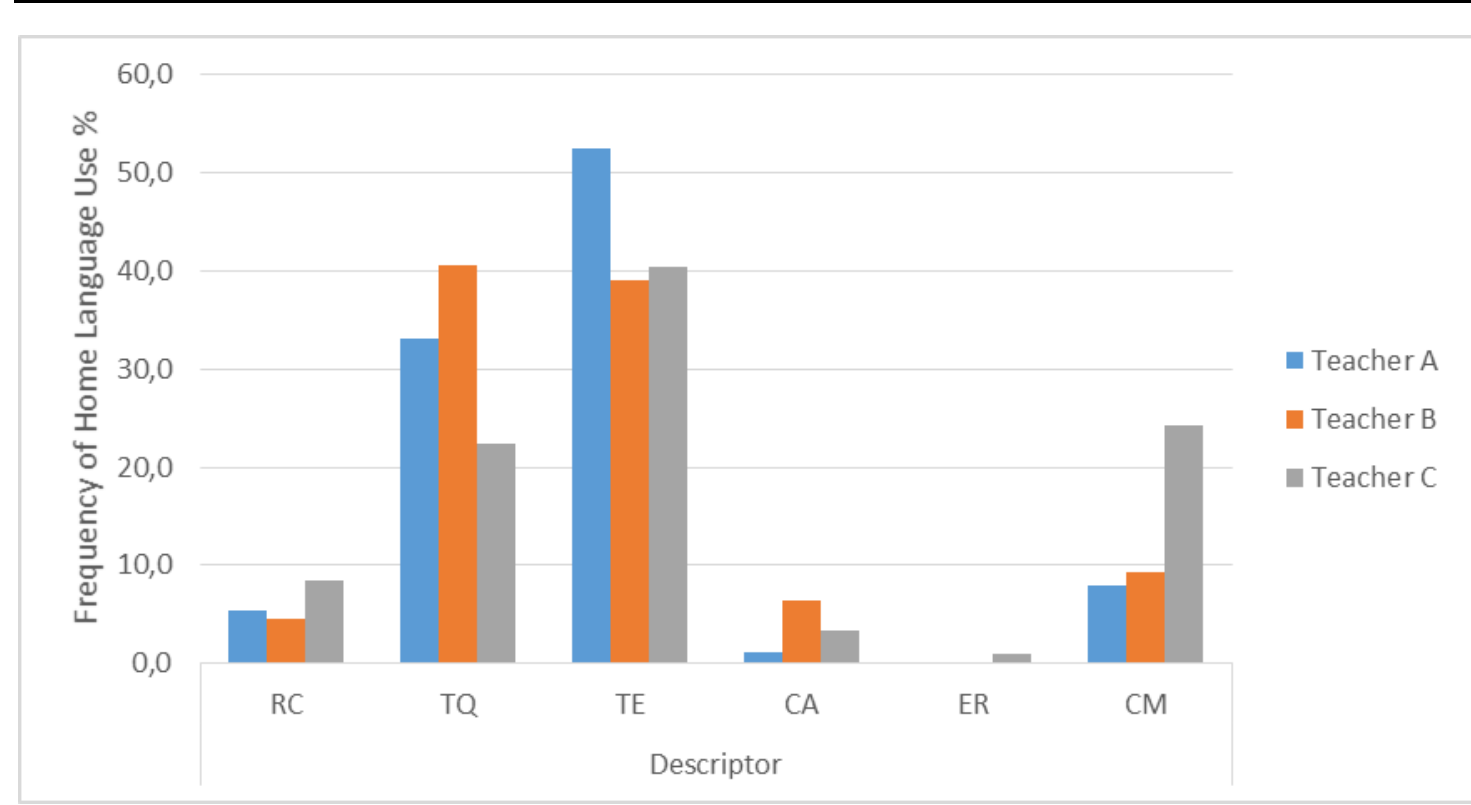

Figure 2. Teachers' Frequency of Home Language across Lesson Categories

Table 4. Excerpt 1

\begin{tabular}{|c|c|c|c|}
\hline \multirow{2}{*}{ Teacher } & \multicolumn{2}{|c|}{ Questions asked } & \multirow{2}{*}{$\begin{array}{l}\text { Cognitive level of } \\
\text { the questions }\end{array}$} \\
\hline & Actual teacher language & English translation & \\
\hline A & Sazintoni kanene nge-isosceles triangle? & What do we know about an isosceles triangle? & Remembering \\
\hline A & $\begin{array}{l}\mathrm{U}-\mathrm{BOD} \text {, can you see } \mathrm{BOD} \text {, what type of an angle } \\
\text { is } \mathrm{BOD} \text { ? /Silence/ BOD siyambona } \mathrm{u}-\mathrm{BOD} \text {, } \\
\text { uyintoni u-BOD pha kula-triangle? Niyambona u- } \\
\text { triangle } \mathrm{AOB} \text {, jonga kengoku u-BOD yena } \\
\text { uyintoni kula-triangle? }\end{array}$ & $\begin{array}{l}B O D \text {, can you see } B O D \text {, what type of an angle } \\
\text { is } B O D \text { ? /Silence/ BOD can you see } B O D \text {, what } \\
\text { is } B O D \text { in that triangle? Can you see triangle } \\
A O B \text {, now look at BOD, what is BOD in that } \\
\text { triangle? }\end{array}$ & Remembering \\
\hline B & $\begin{array}{l}\text { Now we have a scalene triangle siyayibona? i- } \\
\text { scalene triangle kuthwani? }\end{array}$ & $\begin{array}{l}\text { Now we have a scalene triangle can you see it? } \\
\text { What is it? }\end{array}$ & Remembering \\
\hline A & $\begin{array}{l}\text { Siyayazi i-arc? /Yes/ Yintoni i-arc? Masijonge pha } \\
\text { ebhodini, khanindi xelele i-arc pha? Yeyiphi i-arc? }\end{array}$ & $\begin{array}{l}\text { Do we know an arc? /Yes/ What is an arc? Let } \\
\text { us look at the board, what is an arc? Which one } \\
\text { is the arc? }\end{array}$ & Understanding \\
\hline B & $\begin{array}{l}\text { Nizibona ngantoni eza angles zi-equal kula } \\
\text { triangle? }\end{array}$ & $\begin{array}{l}\text { How can you identify the two equal angles in } \\
\text { that triangle? }\end{array}$ & Applying \\
\hline A & $\begin{array}{l}\text { Uyintoni u-BOD pha kula-traingle? La-angle } \\
\text { uyintoni pha kula-triangle? BOD uyintoni kula- } \\
\text { triangle? }\end{array}$ & $\begin{array}{l}\text { What is BOD in that triangle? That angle, what } \\
\text { is it in relation to that triangle? What is BOD to } \\
\text { that triangle? }\end{array}$ & Understanding \\
\hline C & $\begin{array}{l}\text { Singamfumana u-F lo, sisebenzisa eyiphi i- } \\
\text { triangle? }\end{array}$ & We can find this $F$, which triangle can we use? & Understanding \\
\hline $\mathrm{C}$ & Siyamfumana la-F using which traingle? & We can find this $\mathrm{F}$ using which triangle? & Applying \\
\hline
\end{tabular}

\section{Solving Triangles}

Most of the questions Teacher A presented when solving triangles were those that required learners to recall information. In each case if the questions were phrased differently, they would have been classified in other domains of the taxonomy. An example is the third question in the extract below. If it was rephrased to "Why is this triangle a scalene?", then it would become an application question. Some examples are given in excerpt 1 (Table 4).

We found that questions presented in the learners' home language during teaching were mainly reduced to recall. Very few were of the application level and other levels above. The words teachers used in some cases reduced the level of questions to just recall and remembering of facts. The teachers asked the "what" questions most of the time using words like ngubani (what is), uyintoni (what is), yintoni (what is), sazintoni (what do we know), kuthwani (what is it). Not much mathematical thinking was thus required of students due to the nature of questions teachers presented during the teaching of how to solve triangles. Considering that these teachers were teaching Grade 11 classes, questions that required more comprehending, applying, analyzing and synthesizing were 
Table 5. Excerpt 2

\begin{tabular}{|c|c|c|c|}
\hline \multirow{2}{*}{ Teacher } & \multicolumn{2}{|c|}{ Questions Asked } & \multirow{2}{*}{$\begin{array}{c}\text { Cognitive Level of } \\
\text { the Questions }\end{array}$} \\
\hline & Actual Teacher Language & English Translation & \\
\hline A & $\begin{array}{l}\mathrm{BC} \text { intersect with } \mathrm{DC} \text { at } \mathrm{G} \text {, and } \mathrm{DE} \text { niyabona? } \\
\text { Iphi } \mathrm{i} \text {-intersection idibanaphi? Zidibana apha } \\
\text { let's say ngu-G siyabona, right? }\end{array}$ & $\begin{array}{l}\mathrm{BC} \text { intersect with } \mathrm{DC} \text { at } \mathrm{G} \text {, and } \mathrm{DE} \text { can you see? } \\
\text { Where is the intersection? Where do they meet? } \\
\text { They intersect here, let's say its G can you see, } \\
\text { right? }\end{array}$ & Remembering \\
\hline B & $\begin{array}{l}\text { Niyabona u-AC apho kudibana khona u-AC } \\
\text { lo-FG, siyabona? }\end{array}$ & $\begin{array}{l}\text { Can you see } A C \text {, where } A C \text { and } F G \text { intersect, can } \\
\text { you see? }\end{array}$ & Remembering \\
\hline A & U-B ngubani, usezantsi komgca? & What is $B$, it is below the line? & Remembering \\
\hline $\mathrm{B}$ & I-scale sala straight line sithe ngubani? & What did we say the scale of the straight line is? & Remembering \\
\hline A & $\begin{array}{l}\text { Explain the relationship of } B C \text { to } C \text {. Uyintoni } \\
\mathrm{u}-\mathrm{BC} \text { to } \mathrm{C} \text { ? }\end{array}$ & $\begin{array}{l}\text { Explain the relationship of } B C \text { to } C \text {. What is } B C \text { to } \\
C \text { ? }\end{array}$ & $\begin{array}{c}\text { Analysing/ } \\
\text { Understanding }\end{array}$ \\
\hline B & $\begin{array}{l}\text { How do you solve for } A D \text { to be the subject of } \\
\text { formula? Besithe senza njani kanene? Apha } \\
\text { sifuna } U-A D \text { abe yedwa nhe? }\end{array}$ & $\begin{array}{l}\text { How do you solve for AD to be the subject of } \\
\text { formula? By the way, how did we say we do this? } \\
\text { Here we want AD to be alone, right? }\end{array}$ & $\begin{array}{l}\text { Applying/ } \\
\text { Remembering }\end{array}$ \\
\hline C & $\begin{array}{l}\text { Describe with reasons what is } A D \text { is in that } \\
\text { triangle? Yintoni } u-A D \text { ? }\end{array}$ & $\begin{array}{l}\text { Describe with reasons what is } A D \text { is in that } \\
\text { triangle? What is } A D \text { ? }\end{array}$ & $\begin{array}{l}\text { Analysing/ } \\
\text { Understanding }\end{array}$ \\
\hline
\end{tabular}

expected to be presented to these learners. In our observation, critical thinking was thus not adequately promoted in these classes due to how teachers used isiXhosa during the teaching of this concept. Students were thus provided with limited opportunities to think critically during their learning of how to solve triangles.

The questions asked in this section did not allow learners to come up with their own ideas. They were mostly required to remember what they did in the previous lessons or just extract information from the given diagrams without much depth to promote critical thinking. If teachers give themselves opportunities to think carefully before the lesson about their language practices, they could use home language through code-switching more productively formulating higher-order questions that will eventually lead to critical thinking. This will help curb overuse of remembering, recall and rhetoric questions that are less beneficial in aiding and promoting critical thinking.

\section{Transparent Code-switching and Critical Thinking}

A form of code-switching termed transparent code-switching, used by Chikiwa and Schäfer (2016), emerged strongly in this study. This is where isiXhosa terms posed no translation problems because of their familiarity to both the teacher and the pupils to formulate questions. In this section, we focus on some of the questions in which transparent terms were used. Of interest in this section was to see if teachers provided opportunities for critical thinking when they code-switched transparently. These are discussed below.

In excerpt 2 (Table 5), 'intersection' used by Teacher A, is translated to dibana (intersect). Teacher B also used this translation in his questioning when referring to intersection. Dibana (intersect) is an everyday word, which teachers use to mean meet, intersect, or add. The use of dibana (intersect) was transparent in this case for both teachers. The only challenge was that teachers reduced their questions to recall by adding other words like siyabona (can we see), niyabona (can you see) and nhee (right), sithe ngubani (what did we say it is) among others. In some instances, eliminating these words would place the original questions in a different cognitive level. The last three sets of teacher questions in excerpt 2 (Table 5) presents examples of some occurrences where isiXhosa use by the teachers resulted in the lower cognitive level as compared to English version of the same question. Teacher B required learners to 'make $A D$ the subject of formula' and the translation required learners to remember what they had done earlier. The teacher asked 'Besithe senza njani kanene?' (By the way, how did we say we do this?) Teacher $\mathrm{C}$ asked a question that required learners to analyse and provide reasons but on repeating the same question in isiXhosa, learners were only required to demonstrate understanding of what $\mathrm{AD}$ was in the given triangle. The same was noted for Teachers A and B. In this study, we attributed such reduction in the cognitive levels to lack of teacher language use planning, absence of a formal mathematics register in isiXhosa at secondary school and lack of mathematics teachers' training on how to use isiXhosa to teach highly technical and strongly bounded subjects like mathematics.

In the excerpt 3 (Table 6), the transparent word for 'calculate' that teachers used was bala. Bala (calculate) is an everyday word that teachers and pupils use in and outside the classroom. It is also a word that pupils are introduced to in their early years of learning mathematics. Teacher B formulated a question at the synthesis level using bala (calculate). The question requires learners to build up a solution using whatever way they deemed fit. It is not prescriptive of the method they are to use. Nevertheless, in the next question, the same teacher asked a recall question using the same word. 
Table 6. Excerpt 3

\begin{tabular}{cllc}
\hline \multirow{2}{*}{ Teacher } & \multicolumn{2}{c}{ Questions Asked } & $\begin{array}{c}\text { Cognitive Level of } \\
\text { the Questions }\end{array}$ \\
\cline { 2 - 4 } B & $\begin{array}{l}\text { Masiyibale kaloku, yibale ujonge uba } \\
\text { uzawufumana bani. Nifumene bani? }\end{array}$ & $\begin{array}{l}\text { Calculate it and then check what you will get as } \\
\text { an answer. What did you get? }\end{array}$ & Analysing \\
\hline B & Wabala i-gradient, yangubani? & You calculated the gradient, what did you get? & Remembering \\
\hline C & The wabala i-value ka- $\alpha$ yangubani? & You calculated the value of $\alpha$ what did you get? & Remembering \\
\hline B & Itheni i-gradient? & What is wrong with the gradient? & Analysing \\
\hline B & $\begin{array}{l}\text { Kutheni ingafumaneki ngoku? Kutheni } \\
\text { ingafumaneki ngoku i-gradient? }\end{array}$ & $\begin{array}{l}\text { Why can't you find it now? Why is it that you } \\
\text { can't find the gradient now? }\end{array}$ & $\begin{array}{c}\text { Analysing/ } \\
\text { Understanding }\end{array}$ \\
\hline C & Simfumene kengoku u-A, what else? & So now we have found A, what else? & Understanding \\
\hline C & $\begin{array}{l}\text { Yeyiphi esiyifunayo? Umfumene u-A, nabani } \\
\text { omunye, nabani? }\end{array}$ & $\begin{array}{l}\text { Which one are we looking for? We have found } \\
\text { A and what else? }\end{array}$ & Remembering \\
\hline B & $\begin{array}{l}\text { I-tan ye-angle of inclination ilingana } \\
\text { nantoni? }\end{array}$ & Tan of the angle of inclination is equal to what? & Remembering \\
\hline B & U-DR ulingana nabani? & What is DR equal to? & Remembering \\
\hline C & U-angle ACD ulingana nabani kula diagram? & Angle ACD is equal to what in that diagram? & Remembering \\
\hline
\end{tabular}

Teacher B asked two analysis questions about the gradient. Such a mix of questions is to be encouraged in the teaching of mathematics. We argue that questions that span across all domains/ categories are necessary for a quality teaching process. While synthesis and analysis questions were evident in some of the teachers' language, they were practiced at minimal levels. All the teachers in this study frequently asked questions that mainly required learners to remember information. Even in circumstances where these teachers could pose higher-order questions, the use of some home language terms like siyavana, sisonke, niyabona, nhee, in many cases unfortunately reduced their questions to lower-order ones.

While teachers used terms that were transparent to formulate questions of a higher-order, they also used some transparent terms to formulate lower-order questions. Opportunities to encourage critical thinking were thus limited in these circumstances.

\section{Borrowing Code-switching and Critical Thinking}

While all forms of code-switching strategies were evident in teachers' language during questioning, borrowing was most frequent. In this section, we focus on some questions teachers formulated through using a borrowing code-switching strategy.

In all the extracts in excerpt 4 (Table 7), most key terms such as 'cosine rule', 'vertically opposite', 'subtend', 'co-interior', 'transpose', 'angle of inclination', and 'obtuse' were all in their borrowed forms. These are highly mathematical terms first encountered in Grade 10 and are not used in everyday life. Each of these terms were also used precisely to formulate questions during teaching. Most of the questions formulated through borrowing were of various cognitive levels including higher-order. Some opportunities were presented by for learners to think critically. Some words like 'concept', 'condition', and 'deduce' are used in day-to-day lives of both the teacher and the learners. The term 'concept' (ingqiqo according to Teacher B) is more technical even though it is used in everyday life. Its isiXhosa equivalent is not common especially with learners that were part of this study. 
Table 7. Excerpt 4

\begin{tabular}{|c|c|c|c|}
\hline \multirow{2}{*}{ Teacher } & \multicolumn{2}{|c|}{ Questions Asked } & \multirow{2}{*}{$\begin{array}{l}\text { Cognitive Level of } \\
\text { the Questions }\end{array}$} \\
\hline & Actual Teacher Language & English Translation & \\
\hline A & $\begin{array}{l}\text { Kutheni ningazukwazi i- vertically opposite } \\
\text { angles? Sitheni enge- vertically opposite } \\
\text { angles? }\end{array}$ & $\begin{array}{l}\text { Why don't you know vertically opposite } \\
\text { angles? What did we say about vertically } \\
\text { opposite angles? }\end{array}$ & Remembering \\
\hline A & $\begin{array}{l}\text { Teacher A: Kwi- alternate angles, corresponding } \\
\text { angles ne- co-interior angles sizibona ngantoni? }\end{array}$ & $\begin{array}{l}\text { With the alternate angles, corresponding } \\
\text { angles and co-interior angles, how can we } \\
\text { identify them? }\end{array}$ & Understanding \\
\hline B & $\begin{array}{l}\text { Teacher B: Izawuba ndawoni i-angle of } \\
\text { inclination pha ku-line 1? I-angle of inclination } \\
\text { izawuba ndawoni? }\end{array}$ & $\begin{array}{l}\text { Where will the angle of inclination on line } 1 \text { ? } \\
\text { Where will our angle of inclination be? }\end{array}$ & Understanding \\
\hline B & $\begin{array}{l}\text { So sawuqale sithini phaya? Si-transpose nhe? } \\
\text { Then } u-y \text { ibengu } y=3 / 2 x+5 \text { so what will be the } \\
\text { gradient there? }\end{array}$ & $\begin{array}{l}\text { What are we going to do first? We're going to } \\
\text { transpose right? Then y will be } y=3 / 2 x+5 \text { so } \\
\text { what will be the gradient there? }\end{array}$ & Applying \\
\hline B & $\begin{array}{l}\text { I-Cosine rule esizawuyi deducer pha izawuthini? } \\
\text { Izawuthini i-Cosine rule yethu esizawuyi- } \\
\text { deducer phaya? }\end{array}$ & $\begin{array}{l}\text { What will be the Cosine rule that we are going } \\
\text { to deduce? What will our Cosine rule say? }\end{array}$ & Understanding \\
\hline C & $\begin{array}{l}\text { Teacher C: Yeyiphi lo-concept ndiyi sebenzisayo } \\
\text { if i-condition yam iya tshintja ngoku ndinikwa } \\
\text { two sides and included angle? (Lesson 3). }\end{array}$ & $\begin{array}{l}\text { Which concept do I now use if the condition } \\
\text { changes and I'm given two sides and included } \\
\text { angle? }\end{array}$ & Evaluating \\
\hline C & $\begin{array}{l}\text { Why sisithi yi- obtuse angle? Why iyi- obtuse } \\
\text { angle? }\end{array}$ & $\begin{array}{l}\text { Why do we say it's an obtuse angle? Why is it } \\
\text { an obtuse angle? }\end{array}$ & $\begin{array}{l}\text { Analysing/ } \\
\text { Evaluating }\end{array}$ \\
\hline C & Iphi le iyi-subtendayo? & Where is the line that subtends it? & Applying \\
\hline
\end{tabular}

In the interviews, Teachers B and C agreed that there are words used in geometry which do not have an isiXhosa equivalent. Teacher B explains that the best way to teach such words is to pick illustrations from everyday life where such concepts are used. This results in describing the words rather than translating them directly. We noted that for higher-order questions to be fruitfully formulated in this way, teachers would need to think of such illustrations beforehand and not during teaching. Teacher B went on to say that it is not easy to pick appropriate words in the home language to use as translations for these concepts when formulating questions.

During the interviews, Teacher B was asked why he borrowed terms like gradient or cosine rule all the time when asking questions and he said: "I was struggling to find the name for gradient, as a result most of the time I just borrow the word and just say i-gradient. I do not know any particular word that is used for gradient in isiXhosa." Teacher A admitted that it was very difficult to find some appropriate mathematical words in isiXhosa to ask questions and hence her resorting to borrowing. In this study, we found that the borrowing strategy was prevalent during questioning because of, firstly, lack of directly translated mathematical terms in isiXhosa and, secondly, teachers used it to avoid lengthy illustrations of concepts, and lastly inadequate learner language competencies in these classes.

All participating teachers indicated that they do not plan for when and how they use isiXhosa for questioning. Teacher A said: "I do not plan questions in Xhosa before my lessons. I just switch from English to home language whenever I find necessary." This explains the prevalent use of the borrowing strategy observed. Teachers also indicated the lack of materials in isiXhosa. Teacher C mentioned: "I do not use any materials in isiXhosa, I actually do not have any such materials. I rely on my own understanding of mathematics and my Xhosa knowledge." Such lack of materials in the home language explains the high frequency of borrowing done by these teachers during questioning. While borrowing helped teachers formulate some higher-order questions, such terms remained essentially in English except for the prefix.

\section{Leading Teacher Questions}

One aspect that became very evident in teacher questioning was the use of leading questions. These are questions phrased by participating teachers that suggested, prompted or encouraged the answer intended or desired by these teachers.

Teacher A used leading question during her teaching to seek confirmation of progress. The commonly used phrases were 'siyavana sonke' (do you all understand), 'siyayibona sonke' (can we all see), 'nhe' (right) and this is shown in excerpt 5 (Table 8). 
Table 8. Excerpt 5

\begin{tabular}{clll}
\hline \multirow{2}{*}{ Teacher } & \multicolumn{2}{c}{ Questions Asked } & $\begin{array}{c}\text { Cognitive Level of } \\
\text { the Questions }\end{array}$ \\
\cline { 2 - 4 } A & $\begin{array}{l}\text { So this is a right angle isosceles triangle siyavana } \\
\text { sonke nhe? }\end{array}$ & $\begin{array}{l}\text { So this is a right angle isosceles triangle do } \\
\text { you all understand? }\end{array}$ & Remembering \\
\hline A & $\begin{array}{l}\text { Siyabona mos i-vertex ka-angle C? It lies on the } \\
\text { circle, siyabona sonke nhe? }\end{array}$ & $\begin{array}{l}\text { Can we all see the vertex of angle C? It lies on } \\
\text { the circle, can we all see it? }\end{array}$ & Remembering \\
\hline A & $\begin{array}{l}\text { Nanku u-Z shape siyambona sonke? This angle } \\
\text { C2 siyayibona sonke? Therefore angle A is equal } \\
\text { to C2 siyijongile? }\end{array}$ & $\begin{array}{l}\text { Here is your Z-shape, can you see? This angle } \\
\text { C2, can we all see it? Therefore angle A is } \\
\text { equal to C2 are paying attention? }\end{array}$ & Remembering \\
\hline B & Siyayibona nhe? Siyibambile nhe? & Can you see that? Do you understand? & Remembering \\
\hline B & Niyayibona nhe? Niyibambile nhe? & Can you see that? Do you understand? & Remembering \\
\hline B & lyavakala? & Do you understand? & Remembering \\
\hline C & $\begin{array}{l}\text { Arc AD niyabona mos? La-A lowana siyabona } \\
\text { nhe? }\end{array}$ & Can you see arc AD? That A, can you see? & Remembering \\
\hline C & $\begin{array}{l}\text { We are told that this angle is 22 degrees, } \\
\text { akunjalo? }\end{array}$ & $\begin{array}{l}\text { We are told that this angle is 22 degrees, isn't } \\
\text { that so? }\end{array}$ & Remembering \\
\hline
\end{tabular}

During Teacher B's teaching, commonly occurring words that he used to formulate leading questions included 'siyibambile' (do you understand), 'niyibambile' (do you understand), 'siyayibona' (can you see), 'iyavakala' (do you understand). In all these cases, questions phrased using these words solicited chorus answers. The pupils' chorus responses in these particular cases were then interpreted by the teacher as confirming students' understanding of the concepts. This is also evident in some of the other extracts taken from his lessons as given above. Teacher C did not use these terms as frequently as Teachers A and B. He used his own term 'akunjalo' (isn't that so) together with 'niyabona' (can you see) and 'siyabona' (can we see) that other teachers also used.

Teacher B used statements like 'We all got the same thing, right?' In response to this, the class would give a chorus 'yes' except in very few cases where some students were brave enough to respond differently. Teachers A and B used 'nhe' (right) and 'mos' (right) in their questions and to end some of their questions changing these words, or omitting them would transform the question to a higher-order questions (see Tables 5 and 8 ). While these questions might have been meant to serve other purposes, they did not, in our analysis help much in improving and enhancing critical thinking during the teaching, in this case of analytical geometry and trigonometry.

\section{SUMMARY OF FINDINGS AND CONCLUSIONS}

In this study, teachers spent $20 \%$ of their teaching time asking questions in isiXhosa, the learners' home language. The majority of the questions were of the lower-order level according to the revised Bloom's taxonomy. Such questions did not allow learners in these multilingual classes to come up with their own ideas that they could analyse and evaluate during learning. Thus, opportunities were missed to provide for learners in these classes to think critically.

Teachers in this study mostly asked recall and leading questions that did not give learners enough opportunities to think critically and find solutions on their own. A few questions that required comprehension and application, that is, those that required understanding and ability to use learned materials, were least asked in this study. Questions that only required remembering and application were responded to correctly without thinking and understanding. These questions ultimately promoted critical thinking the least during our observations. Questions that encourage learners to do more than just remembering and recalling known facts have a potential of stimulating critical thinking and deeper reasoning (Sillivan \& Lilburn, 2002). Students should not be taught mathematics to only recite mathematical formulas or following algorithms and procedures, but to think critically and mathematically.

In this study, teachers formulated questions using some transparently code-switched terms that were familiar with their learners. While this practice is commendable, it was not widely practiced. In some cases, it was used in such a way that it reduced the level of questions to a lower level, which did not encourage learners to think critically. Teachers are encouraged to plan their questions in advance to ask those questions that will help learners to think deeply and critically about mathematical concepts presented to them. This study recommends careful planning of how and when specialised mathematical terms will be code switched during teaching. Collier (2011) advised that the use of two languages when teaching, if not carefully planned, may lead to pedagogically random codeswitching which may not meet instructional objectives. Such planning can be aided by available teaching materials in learners' home language such as a multilingual learning and teaching resource book in English, isiXhosa, isiZulu and Afrikaans volumes 1 and 2 by Young et al. $(2005,2009)$ and multilingual mathematics dictionaries (for example, Wababa, Welman \& Press, 2010). 
During planning, teachers need to consider some thoughtful ways of introducing and integrating homelanguage mathematical vocabulary in their questions. Teachers should identify and highlight key words required to formulate questions of different cognitive levels. They should consider especially terms that are likely to recur, those with multiple meaning and those that may be problematic. Slavit and Ernst-Slavit (2007) advised that "identifying and carefully planning the use of any such words in a lesson can support students' efforts to follow the subsequent line of discourse" (p. 8). Examples in this study include words like bala that could be interpreted to mean calculate, find and solve; fumana that also could be used to mean find or solve. We thus recommend that teachers' code-switching should provide explicit, meaningful and well-timed language support to students for the enhancement of conceptual teaching in mathematics. Teachers should also be trained to plan how to formulate questions in their home language that will encourage critical and deeper thinking. Such training should be encouraged and incorporated in all structured pre-service and in-service teacher professional development programs.

The main advantage of questions that seek critical thinking is that they in themselves present an invitation to learners to engage in thinking. They cannot be successfully answered without one being largely involved in focused and deeper thinking. Critical-thinking skills are essential to every aspect of mathematics learning, this is because a learner who can think critically will be a better reader, writer, test-taker, and student inside and outside of the classroom (Schneider, 2001). Teachers are thus encouraged to use words in both languages that encourage critical thinking in multilingual classrooms. Huinker and Freckmann (2004, p. 355) acknowledged that "[b]y choosing our words carefully and using intentionally designed questions, we can engage and transform another person's thinking and perspective".

While all the three teachers in this study used borrowing code-switching in the formulation of questions of various cognitive levels during teaching, this was achieved because there was not much effort on the teacher's part to find more transparent terms. They used the 'easy way-out method' of adding an isiXhosa prefix to an English term. Any group of people, like teachers in their classrooms, who regularly talk about mathematical concepts and ideas will have specific ways to succinctly convey their meanings (Meaney, Fairhill \& Trinick, 2008). While these teachers felt the need for, and importance of, home-language use, their strategy was mostly through borrowing. Prevalent use of borrowing which is not transparent suggests the need for intellectualisation of indigenous African languages for them to meaningfully function as the LOLT at secondary school level. The only isiXhosa terms that were transparently used for mathematical purposes were those that teachers and the learners use in everyday life, and those mathematical terms that students were exposed to in the early years of their learning, that is, the Foundation Phase of the South African curriculum where the mathematics register is well developed.

This study concludes that if teachers of mathematics multilingual classes in township and rural schools continue to use predominantly lower-order questions in their pupils' first language, they are depriving their learners of opportunities for meaningful and beneficial engagement with mathematical concepts. In the process, they unintentionally and unconsciously, perpetuate inequalities associated with use of the second language in the teaching and learning of mathematics. Teachers are thus urged and prompted to ask and incorporate a multitude of higher-order questions in isiXhosa that require learners to analyze, evaluate and create their own thinking and procedures whilst code-switching. This can be achieved through careful prior planning of questions in consultation with mathematical materials available in learners' home language. Such practices will create rich teaching and learning environments that fosters critical thinking in multilingual mathematics classrooms.

\section{REFERENCES}

Adler, J. (2001). Teaching mathematics in multilingual classrooms. Dortrecht: Kluwer Academic Publisher.

Alidou, H., \& Brock-Utne, B. (2011). Teaching practices - teaching in a familiar language. In A. Ouane, \& C. Glanz (Ed.), Optimising learning, education and publish in Africa: the language factor. A review and analysis of theory and practice in mother tongue and bilingual education in sub-Saharan Africa (pp. 159-186). UIL/ADEA.

Anderson, L. W. (2002). Curricular alignment: A re-examination. Theory into Practice, 41(4), $255-260$. https://doi.org/10.1207/s15430421tip4104_9

Anderson, L. W., \& Krathwohl, D. R. (Eds.). (2001). A taxonomy for learning, teaching and assessing: A revision of Bloom's Taxonomy of educational objectives: Complete edition. New York: Longman.

Baker, C. (1993). Foundations of bilingual education and bilingualism. Cleveland, Philadelphia: Multilingual Matters.

Baker, M. (2011). In other words. A coursebook on translation. 2nd Edition. London \& New York: Routledge.

Carnoy, M., Chisholm, L., Addy, N., Arends, F., Baloyi, H., Irving, M., \& Sorto, A. (2011). The process of learning in South Africa: The quality of Mathematics teaching in North West Province; Technical Report 11 June 2011. Pretoria: HSRC and Stanford University. 
Chick, J. K. (1996). Safe-talk: Collusion in apartheid education. In H. Coleman (Ed.), Society and the Language Classroom (pp. 21-39). Cambridge: Cambridge University Press.

Chikiwa, C., \& Schäfer, M. (2016). Teacher code switching consistency and precision in a multilingual mathematics classroom. African Journal of Research in Mathematics, Science and Technology Education (AJRMSTE), 20(3), 244255. https:/ / doi.org/10.1080/18117295.2016.1228823

Choudhury, M., \& Bose, A. (2011). An investigation of the role of language negotiations in a multilingual mathematics classroom. In. In M. Setati, T. Nkambule, \& L. Goosen (Eds.), Proceedings of the ICMI Study 21 Conference: (pp. 28-37). Sào Paulo, Brazil: ICMI.

Clasen, D. R., \& Bonk, C. (1990). Teachers tackle thinking. Madison, WI: Madison.

Collier, C. (2011). Seven steps to separating difference from disability. Thousand Oaks, CA: Corwin. https://doi.org/10.4135/9781452219424

Cummins, J. (2000). Language, power and pedgogy: Bilingual children in the crossfire. Clevedon: Multilingual Matters. https:// doi.org/10.21832/9781853596773

Denzin, N. K., \& Lincoln, Y. S. (2000). The discipline and practice of qualitative research. In N. K. Denzin, \& Y. S. Lincoln, Handbook of Qualitative Research (2nd ed.). London: Sage Publication.

Department of Basic Education, DBE. (2011). Curriculum and Assessment Policy Statement, CAPS, Grade 10-12. Mathematics.

Dori, Y. J., \& Herscovitz, O. (1999). Question posing capability as an alternative evaluation method: Analysis of an environmental case study. Journal of Research in Science Teaching, 36(4), 411-430. https:/ / doi.org/10.1002/(SICI)1098-2736(199904)36:4<411::AID-TEA2>3.0.CO;2-E

Duron, R., Limbach, B., \& Waugh, W. (2006). Critical thinking framework for any discipline. International Journal of Teaching and Learning in Higher Education, 187(2), 160-66.

Elder, L., \& Paul, R. (1994). Critical thinking: Why we must transform our teaching. Journal of Developmental Education, 18(1), 34-35.

Essien, A. (2013, June 02). Maths still best taught in English. Mail \& Guardian.

Gumperz, J. J. (1982). Discourse strategies. London: Cambridge University Press. https:/ / doi.org/10.1017/CBO9780511611834

Huinker, D., \& Freckmann, J. L. (2004, March). Focussing conversations to promote teacher thinking. Teaching Children Mathematics, 10(7), 352-357.

Limbach, B., \& Waugh, W. (2010). Developing higher level thinking. Journal of Instructional Pedagogies, 3, 1-9.

Mafela, L. (2009). Code switching in Botswana history classrooms in the decade for sustainable development. Language matters, 40(1), 56-79. https:/ / doi.org/10.1080/10228190903055568

Meaney, T., Fairhill, U., \& Trinick, T. (2008, June). The role of language in ethnomathematics. The Journal of Mathematics and Culture, 3(1).

Meaney, T., Trinick, T., \& Fairhill, U. (2012). Collaborating to meet language challenges in indigenous mathematics classrooms. London: Springer. https:/ / doi.org/10.1007/978-94-007-1994-1

Mercer, N. (1995). The guided construction of knowledge: Talk amongst teachers and learners. Clevedon: Multilingual Matters.

Owen-Smith, M. (2010). The language challenge in the classroom: A serious shift in thinking and action is needed. The Language Challenge, 31-37. Retrieved Retrieved on 1 May 2018 from http://hsf.org.za/resourcecentre/focus/focus-56-february-2010-on-learning-and-teaching/the-language-challenge-in-the-classrooma-serious-shift-in-thinking-and-action-is-needed/download

Paul, R. (2007, July). Critical thinking in every domain of knowledge and belief. The 27th Annual International Conference on Critical Thinking. July 23, 2007. Berkeley, CA: Center for Critical Thinking. Retrieved on 1 May 2018 from http://www.criticalthinking.org/pages/critical-thinking-in-every-domain-of-knowledge-andbelief/698

Paul, R. W. (1990). CHAPTER 4: Critical thinking: What, why, and how. In A. J. Binker (Ed.), Critical thinking: What every person needs to survive in a rapidly changing world (pp. 45-56). Rohnert Park. CA 94928: Center for Critical Thinking and Moral Critique: Sonoma State University.

Paul, R., \& Elder, L. (2008). The miniature guide to critical thinking, concepts and tools. California: The Foundation for Critical Thinking Press. Retrieved on 1 May 2018 from https://www.criticalthinking.org/files/Concepts_Tools.pdf

Pimm, D. (1987). Speaking mathematically: Communication in mathematics classrooms. London: Routledge. 
Prediger, S., Clarkson, P., \& Bose, A. (2012). A way forward for teaching in multilingual contexts: Purposefully relating multi lingual registers. 12th International Congress on Mathematical Education TSG 30: Mathematics education in a multilingual and multicultural environment (pp. 6213-6222). Seoul, Korea: ICME-12.

Probyn, M. J. (2009). "Smuggling the vernacular into the classroom": Conflicts and tensions in classroom code switching in township/rural schools in South Africa. International Journal of Bilingual Education and Bilingualism, 12, 123-136. https:/ / doi.org/10.1080/13670050802153137

Probyn, M. J. (2015). Pedagogical translanguaging: Bridging discourses in South African science classrooms. Language and Education, 29(3), 218-234. https://doi.org/10.1080/09500782.2014.994525

Qashoa, S. H. (2013). Effects of teacher question types and syntactic structures on EFL classroom interaction. The International Journal of Social Sciences, 7(1), 52-62.

Rose, S., \& van Dulm, O. (2006). Functions of code switching in multilingual classrooms. A Journal for Language Learning, 1-13.

SA Statistics. (2012). South African Statistics. Pretoria: Statistics South Africa.

Schneider, V. (2001). Stepping stones: A path to critical thinking, volume 1. Pittsford, NY: Castle Rock.

Setati, M. (2005). Mathematics education and language: Policy, research and practice in multilingual South Africa. In R. Vithal, J. Adler, \& C. Keitel, Math Education Research in South Africa: Perspectives, practices and possibilities (pp. 73-109). Pretoria: HSRC.

Setati, M. (2008). Access to mathematics vs access to the language of power: The struggle in multilingual classrooms. South African Journal of Education, 28, 103-116.

Setati, M., \& Adler, J. (2001). Between Languages and discourses: language practices in primary multilingual mathematics classrooms in South Africa. Educational Studies in Mathematics, 43(3), 241-269.

Setati, M., Adler, J., Reed, Y., \& Bapoo, A. (2002). Incomplete Journeys: Code-switching and other language practices in mathematics, science and English language classrooms in South Africa. (2, Trans.) Language and Education, 16(2), 128-149. https:/ / doi.org/10.1080/09500780208666824

Sillivan, P., \& Lilburn, P. (2002). Good questions for math teaching: Why ask them and what to ask. Sausalito, CA: Grades K-6 Math Solutions.

Slavit, D., \& Ernst-Slavit, G. (2007). Teaching mathematics and English to English language learners simultaneously. Middle School Journal, 39(2), 4-11. https:/ / doi.org/10.1080/00940771.2007.11461618

South African Language in Education Policy (LiEP). (1997). South African Language in Education Policy of 1997. Department of Basic Education.

Statistics South Africa. (2011). Census 2011: Census in brief. Pretoria: Statistics South Africa.

Then, D. C., \& Ting, S. H. (2011). Code-switching in English and science classrooms: more than translation. International Journal of Multilingualism, 8(4), 299-323. https:/ / doi.org/10.1080/14790718.2011.577777

Wababa, Z., Welman, K., \& Press, K. (2010). Isichazi-magama seziBalo Sezikolo sase-Cambridge. Cape Town: Cambridge University Press.

Wildsmith-Cromarty, R. (2012). Reflections on a research initiative aimed at enhancing the role of African languages in education in South Africa. Journal for Language Teaching, 46(2), 157-170.

Young, D., van der Vlugt, J., Qanya, S., Abel, L., Brombacher, A., Clark, J., \& Solomons, G. (2009). Understanding concepts in mathematics and science. Volume 2: A multilingual learning and teaching resource book in English, IsiXhosa, IsiZulu and Afrikaans. Cape Town: Maskew Miller Longman.

Young, D., van der Vlugt, J., Qanya, S., Abel, L., Brombacher, A., Clark, J., \& Zuma, S. (2005). Understanding concepts in Mathematics and Science: A multilingual learning and teaching resource book in English, IsiXhosa, IsiZulu and Afrikaans. Cape Town: Maskew Miller Longman.

Zuma, S. C., \& Dempster, E. R. (2008). IsiZulu as a language of assessment in Science. African Journal of Research in SMT Education, 12(2), 31-46. https:/ / doi.org/10.1080/10288457.2008.10740633

\section{http://www.ejmste.com}

